\title{
Investigation of Relationship between Service Quality Dimensions and Customers' Satisfaction (Case study: Saderat Bank Branches in Tehran City, Iran)
}

\section{Somayeh Tavanazadeh}

Department of Business Management, Qazvin Branch, Islamic Azad University, Qazvin, Iran *Corresponding Author: Email: Tavanazadeh.so@gmail.com

\author{
Mansoureh Aligholi \\ Department of Business Management, Faculty of Management, \\ Central Tehran Branch, Islamic Azad University, Tehran, Iran
}

\section{Doi:10.5901/mjss.2014.v5n20p3116}

\begin{abstract}
In the past, services were less important than products but today, this is service which receives the most attention by organizations. In advanced countries, economy focus has been shifted from product to service and this is a long-term tendency in today's world. The present research aims to investigate relationship between service quality dimensions and customers' satisfaction and tries to explain customers' satisfaction concept considering the impact of service quality dimensions on customers' satisfaction. The present research is a descriptive-survey study and sampling method was systematic random sampling. 267 questionnaires were distributed among customers of Saderat Bank all over Tehran City. Correlation and regression techniques were used for data analysis. Results of the hypotheses test showed that all dimensions of service quality dimensions have positive and significant relationship with customers' satisfaction.
\end{abstract}

Keywords: Customers' Satisfaction, Service Quality Dimensions, Trust, Tangibles, Empathy, Responsiveness, Confidence

\section{Introduction}

Serving customers is the oldest and also the newest issue for any organization. Most researchers believe that for most firms, the most certain way for continuing life and achieving success is to embed service quality in customers' minds. Contrary to products which have special scales like durability and defect for measuring quality, service performance is intangible and inhomogeneous and customers' experience from received services are different. Further, production and consumption of service quality cannot be separated from each other because service is produced by an organization and is consumed by customers (Zitamel and Parasuraman, 2008). In the present world, quality has challenged organizations a lot and it has become very popular in service sector. If service quality makes customers satisfied or excels their expectations, quality level will be considered as high and it will be reflected in the form of customers' satisfaction. In fact, what a customer receives from a service is a share of his or her satisfaction with the service. Considering the importance of customers' satisfaction in receiving services, we try to specify relationship between components of service quality in Saderat Bank and its customers' satisfaction.

\section{Theoretical fundamentals}

In any organization, whether production or service, customers are the most important factor in organizational conservation and if an organization is not able to attract satisfaction and loyalty, it will damage its long-term growth (Rahnama et al, 2012). It can be said that the most important professional skill of marketers is their ability to create, maintain, protect and promote brand. Marketers believe that determination of brand is the art and base of marketing (Heidarzadeh, Khoshpanjeh and Rahnama, 2011). Competition among firms for acquiring more shares of market and customers' attempt to reach higher levels of satisfaction has made firms to look for achieving prize status in the market and customers to find clues for finding the best suppliers. These two targets have close relationship with two concepts: service quality and customers' satisfaction. Investigation of these two concepts in service markets is of great importance for service companies. It must be noted that loyal customers bring many advantages. These include improvement of organizational profitability, reduction in marketing costs, and increase in corporate sales, low price sensitivity of customers and so on (Rahnama et al, 2012). Within the past few years, high level of service quality provided for customers has been considered as an instrument to reach competitive advantages. In order to have a long-term relationship with customers, banks must know how they can provide high-quality services. In customers' strategy, 
customer's loyalty is of strategic importance for any organization. Increase in customers' loyalty is a common subject among university managers and advisors (Haghighi et al, 2012).

\section{Service quality definition}

Service quality is an important factor for organizational growth and success and is of great strategic importance for management (Sahny et al, 2006). The most complete definition of service quality has been presented by Parasuraman et al: "service quality is a form of attitude towards satisfaction but not exactly the same as satisfaction and is obtained by comparing customers' expectations from services and services performance" (Atafar and SHafiee, 2006).

\section{Service quality measurement models}

There are different models for measuring service quality. We review two of these models in here.

\subsection{Lehtinen and Lehtinen model}

These two researchers presented three dimensions for service quality:

Physical quality: physical quality refers to products or supporting items of products and services. Financial products have limited physical dimensions. Therefore, other physical evidences are usually used for evaluation of service quality. For instance, customers evaluate quality using decoration, facilities and equipment inside branches and ... .

Interactive quality: interactive quality refers to interactions between customers and service providers. These interactions may occur in different forms, for instance, face to face interaction or via instruments like phone or internet.

Corporate quality: corporate quality refers to general perception and image of an organization and is an intangible dimension. Therefore, perceptions of overall corporate quality are related to the above factors (Harrison, 2000).

\subsection{Servqual model}

This service quality model was introduced by Parasuraman et al in 1985 and is now considered as a standard instrument for measuring service quality. This instrument is called SERVQUAL in service quality literature. In its general and primary form, this model has 22 pairs of items. Half of these items measure expected level of quality by respondents and the other half evaluate perceived quality level. This may be attributed to internal simplicity of relationship between service quality perception and internal organizational factors. After doing basic studies in the field of service quality, standards were combined to form Servqual model. Service quality or Servqual is made up of two words: service and quality. In this model, after investigation of customers' expectations of service quality, we determine and measure gaps between factors affecting service quality (management perception, service quality characteristics, quality of service offered to customers, relationship with customers) and identified expectations in the first stage (Akbariyan, 2004). Managers must have potential competencies, knowledge and long-term experience and socio-communicational skills and an effective management starts from objectives. Further, managers must rely on resources and especially human force.

\section{Service quality dimensions}

Five dimensions of service quality are listed in table 1. These dimensions were derived after doing some studies by Servqual model in service industries like universities, banks, credit cards, overhaul, maintenance and communications.

\begin{tabular}{|l|l|}
\hline tangibles & Tangibles: equipment and facilities, personnel, organizational environment and ... \\
\hline reliability & Reliability: ability to serve customers properly \\
\hline responsiveness & Responsiveness: tendency to help customers and serve them on time. \\
\hline Security confidence polite behavior competency & $\begin{array}{l}\text { Confidence: employees' knowledge and skill in promotion and inspiration of trust } \\
\text { in customers }\end{array}$ \\
\hline $\begin{array}{l}\text { accessibility communications } \\
\text { customers' understanding }\end{array}$ & Empathy: employees' attention and care about customers' when serving them \\
\hline
\end{tabular}

\section{Customer's satisfaction definition}

Many definitions have been presented for customers' satisfaction in marketing literature. Here are several definitions:

- Customers' satisfaction is usually considered as a sense or judgment about a product or service after consumption by customers (Jamal \& Nasser, 2002).

- Customer's satisfaction means a favorable or unfavorable feeling of a person which forms as a result of 
comparing mental performance with expectations (Kotler, 2010).

- Customer's satisfaction is a result of comparing expected performance before purchase and real perceived performance after purchase (Beerli, Martin \& Quintana, 2004).

Satisfaction is a positive response and is resulted from an expectable experience. Before a new purchase, customers compare their expectations with previous experience(Vazifehdoost, Rahnama \& Mousavian, 2014).

\section{Research background}

There are many studies indicating significant relationship between service quality and customers' satisfaction. A summary of these studies are listed in table (1).

Table 1: a summary of internal and external studies conducted on research subject

\begin{tabular}{|c|c|c|c|c|}
\hline year & researcher & country & title & results \\
\hline 2011 & $\begin{array}{l}\text { Sobhanifard and } \\
\text { Kharraziyan }\end{array}$ & Iran & $\begin{array}{l}\text { Determination of strategic } \\
\text { priority in order to improve } \\
\text { bank customers' service } \\
\text { quality }\end{array}$ & $\begin{array}{l}\text { In addition to introduction of indices for measuring service quality offered to customers, } \\
\text { their results showed that } 8 \text { indices out of } 24 \text { indices of service quality evaluation are in } \\
\text { top priority and therefore banks must improve them. These } 8 \text { indices are as follows: } \\
\text { Coverage of every kind of bank need, possibility of adding special options for special } \\
\text { cases, information offering using personal profile, provision of appropriate information at } \\
\text { work and standby, rapid account loading, appropriate feedback service, special services } \\
\text { for special individuals (children, the old, non-Persians, the disabled ) }\end{array}$ \\
\hline 2010 & $\begin{array}{l}\text { Adel Azar and Ali } \\
\text { MOhammadlou }\end{array}$ & Iran & $\begin{array}{l}\text { Design of service quality } \\
\text { model in supply chain: } \\
\text { explanation of mutual } \\
\text { service quality concept }\end{array}$ & $\begin{array}{l}\text { Results showed that there is a significant gap between suppliers' procurement } \\
\text { performance targets and their understanding of performance. The difference between } \\
\text { procurement performance perceived by central company and what is perceived by } \\
\text { suppliers was significantly negative. This means that suppliers' perception of their } \\
\text { performance was more than that of the central company's. }\end{array}$ \\
\hline 2010 & Adel Azar et al & Iran & $\begin{array}{l}\text { Evaluation of public sector } \\
\text { service quality using fuzzy } \\
\text { data }\end{array}$ & $\begin{array}{l}\text { They observed that relative proximity index obtained for customers' expectations and } \\
\text { perceptions of services showed that there was a significant difference between these } \\
\text { two items. This shows inadequacy of service quality from customers' viewpoints. There } \\
\text { was also a gap between customers' expectations and employees' perceptions. This may } \\
\text { be resulted from an improper understanding of customers' expectations. }\end{array}$ \\
\hline 2012 & $\begin{array}{l}\text { Hamidizadeh and } \\
\text { Ibrahimi }\end{array}$ & Iran & $\begin{array}{l}\text { Development of a model } \\
\text { for evaluation of the } \\
\text { quality of hardware and } \\
\text { software in banking } \\
\text { industry }\end{array}$ & $\begin{array}{l}\text { Results of this research showed that hardware and software dimensions are important } \\
\text { components for service quality. Moreover, hardware dimension had a greater weight in } \\
\text { forming bank service quality concept in comparison with software dimension. }\end{array}$ \\
\hline 2010 & SeyyedJavadin Et al & Iran & $\begin{array}{l}\text { A model for evaluation of } \\
\text { impact of service quality } \\
\text { on sports services } \\
\text { customers' loyalty }\end{array}$ & $\begin{array}{l}\text { Results of this research showed that gyms service quality and sports complexes service } \\
\text { quality and customers' satisfaction influence on loyalty. Further, results of this research } \\
\text { showed that loyal behaviors are multi-dimensional and none of the indices can predict } \\
\text { customers' loyalty on its own. }\end{array}$ \\
\hline 2010 & $\begin{array}{l}\text { Shahin and } \\
\text { Abolhasani }\end{array}$ & Iran & $\begin{array}{l}\text { Evaluation of difference } \\
\text { between service quality } \\
\text { characteristics and service } \\
\text { offering in insurance } \\
\text { industry (case study: Iran } \\
\text { insurance Company } \\
\text { branches in Isfahan City). }\end{array}$ & $\begin{array}{l}\text { The magnitude of internal gap in service quality in Iranian Insurance Company in Isfahan } \\
\text { City was equal to } 2.2359 \text {. Therefore, in order to decrease this gap, they recommended } \\
\text { paying higher salaries and rewards like financial awards and promotions to employees } \\
\text { who serve customers well. }\end{array}$ \\
\hline 2012 & Agbor & Sweden & $\begin{array}{l}\text { Relationship between } \\
\text { customers' satisfaction } \\
\text { and service quality: case } \\
\text { study: three service } \\
\text { companies in Omea }\end{array}$ & $\begin{array}{l}\text { This research showed that there are different results obtained from investigation of } \\
\text { relationship between service quality dimensions and service quality/customers' } \\
\text { satisfaction. Further, results showed that flexibility, empathy and reliability dimensions of } \\
\text { service quality are significant. Reliability and empathy for customers' satisfaction was } \\
\text { significant but flexibility for customers' satisfaction was not significant. In the end, results } \\
\text { showed that service quality had a significant relationship with customers' satisfaction. }\end{array}$ \\
\hline 2014 & Dinh\&Pickler & Vietnam & $\begin{array}{l}\text { Investigation of service } \\
\text { quality and customers' } \\
\text { satisfaction in Vietnam's } \\
\text { banking industry }\end{array}$ & $\begin{array}{l}\text { Results of this research showed that demographic nature and banking features have } \\
\text { significant relationship with perceived service quality. Moreover, results showed that the } \\
\text { five dimensions of quality have significant relationships with each other and explain } \\
38.6 \% \text { of relationship between service quality and customers' satisfaction in Vietnamese } \\
\text { banking industry. }\end{array}$ \\
\hline 2014 & $\begin{array}{l}\text { Navaratnaseelan\&EI } \\
\text { angkumaran }\end{array}$ & Serilanka & $\begin{array}{l}\text { Impact of service quality } \\
\text { on customers' satisfaction: } \\
\text { case study: customers of } \\
\text { commercial banks of } \\
\text { Trinkofinancial region } \\
\end{array}$ & $\begin{array}{l}\text { Pearson correlation coefficient showed that there is a positive and significant relationship } \\
\text { between service quality and customers' satisfaction. Further, this research showed that } \\
\text { service quality has a significant impact on customers' satisfaction. }\end{array}$ \\
\hline 2011 & $\begin{array}{l}\text { Alhamadani\& } \\
\text { Mohammad }\end{array}$ & Jordan & $\begin{array}{l}\text { Investigation of service } \\
\text { quality and customers' } \\
\text { satisfaction in Jordan's } \\
\text { banking industry }\end{array}$ & Results showed that service quality has a lot of impacts on customers' satisfaction. \\
\hline
\end{tabular}




\section{Research conceptual model}

Servqual model was used for evaluation of service quality and satisfaction of customers. This model was presented by Parasuraman et al (1980) for evaluation of service quality. This model tries to measure service quality in environments in which service quality is considered as a must for understanding customers. Figure 1 presents research conceptual model.

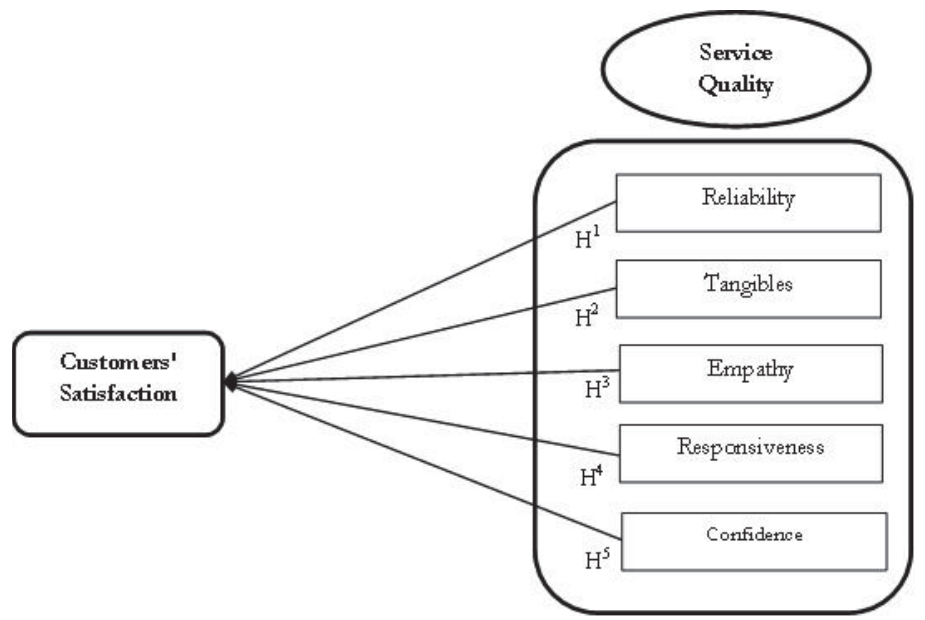

Figure 1: research conceptual model

Considering research conceptual model, research hypotheses are as follows:

- There is a significant relationship between customers' perception of reliability dimension of services provided by Tehran City Saderat Bank branches and customers' satisfaction.

- There is a significant relationship between customers' perception of tangibles dimension of services provided by Tehran City Saderat Bank branches and customers' satisfaction.

- There is a significant relationship between customers' perception of empathy dimension of services provided by Tehran City Saderat Bank branches and customers' satisfaction.

- There is a significant relationship between customers' perception of responsiveness dimension of services provided by Tehran City Saderat Bank branches and customers' satisfaction.

- There is a significant relationship between customers' perception of confidence dimension of services provided by Tehran City Saderat Bank branches and customers' satisfaction.

\section{Materials and methods}

\subsection{The questionnaire}

Questionnaire was used as data collection instrument. The questions were designed according to Likert's five-point scale from "completely disagree" to "completely agree". After preparation of the questionnaire, 30 questions were distributed among customers as a pretest and for testing reliability. Cronbach's alpha was used for investigation of reliability. Results showed that Cronbach's alpha coefficient for total questionnaire was above 0.7. Further, reliability of the questionnaire was verified by experts. Therefore, the questionnaire had acceptable reliability and validity.

\subsection{The sample}

Statistical population of the research included all customers who used Saderat Bank services across Tehran City. 300 questionnaires were randomly distributed among customers. 268 usable questionnaires were returned. Return rate of the questionnaires was therefore equal to 0.89 (268/300). 


\section{Data analysis}

\subsection{Investigation of normality of data distribution}

Kolmogrov-Smearnov test was used to investigate normality of data distribution. Results of this test are summarized in table 2.

Table 2: investigation of normality of data distribution

\begin{tabular}{|c|c|c|c|}
\hline Significance level & Degree of freedom & statistic & variables \\
\hline 000.0 & 267 & 130.0 & reliability \\
\hline 000.0 & 267 & 124.0 & tangibles \\
\hline 000.0 & 267 & 111.0 & empathy \\
\hline 000.0 & 267 & 113.0 & responsiveness \\
\hline 000.0 & 267 & 099.0 & confidence \\
\hline 000.0 & 267 & 127.0 & satisfaction \\
\hline
\end{tabular}

As it can be seen, all variables have non-normal distribution because significance levels of the variables are below 0.05 . Consequently, non-parametric tests were used for testing the hypotheses.

Investigation of Saderat bank customers' satisfaction

Non-parametric binomial test was used for investigation of customers' satisfaction because data distribution was not normal. Results are summarized in table 3.

Table 3: binomial test of customers' satisfaction

\begin{tabular}{|cc|c|c|c|c|c|}
\hline & & Category & $\mathrm{N}$ & Observed Prop. & Test Prop. & Exact Sig. (1-tailed) \\
\hline \multirow{4}{*}{ Satisfaction } & Group 1 & $<=3$ & 64 & .2 & .5 & $.000^{\mathrm{a}}$ \\
& Group 2 & $>3$ & 203 & .8 & & \\
& Total & & 267 & 1.0 & & \\
\hline
\end{tabular}

a. Alternative hypothesis states that the proportion of cases in the first group $<.4$.

Considering the results of binomial test, Sig value is smaller than alpha $=0.05$. therefore, in $95 \%$ certainty level, it can be said that Saderat Bank is in good status in terms of customers' satisfaction (above average(3)).

Research hypotheses test

Correlation test was used for testing research hypotheses. Considering the non-normal distribution of the variables, Spearman correlation test was used. Results of testing research hypotheses using Spearan correlation coefficient are summarized in table 4.

Table 4: research hypotheses test

\begin{tabular}{|c|c|l|}
\hline Significance & Correlation & \multicolumn{1}{c|}{ Hypothesis } \\
\hline 0.000 & 0.566 & $\begin{array}{l}\text { There is a significant relationship between reliability of service quality of } \\
\text { Saderat Bank in Tehran City and customers' satisfaction. }\end{array}$ \\
\hline 0.000 & 0.534 & $\begin{array}{l}\text { There is a significant relationship between tangibles of service quality of } \\
\text { Saderat Bank in Tehran City and customers' satisfaction. }\end{array}$ \\
\hline 0.000 & 0.473 & $\begin{array}{l}\text { There is a significant relationship between empathy of service quality of } \\
\text { Saderat Bank in Tehran City and customers' satisfaction. }\end{array}$ \\
\hline 0.000 & 0.523 & $\begin{array}{l}\text { There is a significant relationship between responsiveness of service quality of } \\
\text { Saderat Bank in Tehran City and customers' satisfaction. }\end{array}$ \\
\hline 0.000 & 0.425 & $\begin{array}{l}\text { There is a significant relationship between confidence of service quality of } \\
\text { Saderat Bank in Tehran City and customers' satisfaction. }\end{array}$ \\
\hline
\end{tabular}

Investigation of research hypotheses shows that all research hypotheses are verified. Further, reliability dimensions 
(factor loading $=0.566$ and significance number $=0.000$ ) has the strongest relationship with customers' satisfaction. Further, confidence dimension has the weakest relationship with customers' satisfaction.

\section{Conclusion and discussion}

Evaluation of customers' satisfaction is of great importance in today's business world. Customers' satisfaction is a feeling and it must be quantified in order to be able to measure and improve it. Customers' satisfaction models are solutions for this process. Data collection for these models is conducted using questionnaires. Results of studies conducted by Samadi and Eskandari (2010), SalehiKordabadi (2010), Naseriyan et al (2010), Agbor (2011), Din and Piklerdez (2014), Navart and Elang (2014), Ravi Shendran (2010), Mohammad and Alhamdani (2011), Navart and Elang (2014) also showed that there is a significant relationship between reliability dimension and customers' satisfaction. Therefore, result of this hypothesis test in this research conforms to the results of previous similar studies. Fortunately, Saderat Bank has adopted acceptable polices in this regard but still requires more attempts. Since this bank is new to Iranian banking industry in comparison with old banks like Melli and Mellat, it is necessary to establish long-term relationships with customers and obtain more shares of the market and create loyal customers. Of course, it must be noted that banks and financial institutes must emphasize on differentiation of their services because customers of banks are result-oriented and function-oriented. Profitable companies are those that evaluate their customers' satisfaction efficiently and continuously and try to improve it. This makes customers' satisfaction value clear. Considering the results of the research and customers' satisfaction, we can understand the importance and the role of service quality in increasing customers' satisfaction. Results of this research showed that there is a significant relationship between reliability, tangibles, responsiveness, empathy and reliability dimensions and customers' satisfaction in Saderat Bank. As final conclusion, as it was said before, results of this research showed that there is a positive and significant relationship between service quality of Saderat bank and customers' satisfaction.

\section{References}

Agbor, Jenet. (2011). "The Relationship Between Customer Satisfaction and Service Quality: a study of three service sectors in Umea", Umea School of Business, Masters Thesis, two-years, 30hp.

Akbariyan, Gholam Reza, (2004), evaluation of servie quality diemnsions using servqual 5-dimensional model (case study: Mehrabad Customs), master degree thesis, Tehran, ZShahidBeheshti University.

Azar, Adel and Mohammadlou, Moslem (2010). "service quality model design in supply chain: explanation of bilateral service quality concept", business management vision, number 1, pp: 23-41.

Azar, Adel, RezaeePandari", Abbas and Jafarinejad, Navid (2010), "evaluation of service quality in public sector using fuzzy data", journal of executive management, number 2, pp: 13-38.

Beerli, A., Martin, J. D., \& Quintana, A., (2004), "A model of customer loyalty in the retail banking market", European Journal of Marketing, 38, 253-275.

Dinh, Van and Pickler, Lee. (2014). "Examining Service Quality and Customer Satisfaction in the Retail Banking Sector in Vietnam", Journal of Relationship Marketing, 11:4, pp 199-214.

Haghighi, Mohammad; Dorosti, Ali; Rahnama, Afshin; Hoseinpour, Ali;(2012) 'Evaluation of factors affecting customer loyalty in the restaurant industry' African Journal of Business Management Vol. 6(14), pp. 5039-5046.

Hamidizadeh, Mohammad Reza and Ibrahimi, Abolghasem (2012), "development of a model for evaluation of hardware and software quality in banking industry", business amangement quarterly, number 4, pp: 65-78.

Harrison, T., (2000), "Financial services marketing", Prentice Hall. Great Britain.

Heidarzadeh Hanzaee, Kambiz; Khoshpanjeh, Mahsa \& Rahnama, Afshin; "Evaluation of the effects of product involvement facets on brand loyalty" African Journal of Business Management Vol. 5(16), pp. 6964-6971, 18 August, 2011.

Jamal, A., \& Naser, K., (2002), "Customer satisfaction and retail banking: An assessment of some of the key antecedents of customer satisfaction in retail banking", International Journal of Bank Marketing, 20, 146-160.

Mohammad, Anber and Alhamadani, Shireen.(2011). "Service Quality Perspectives and Customer Satisfaction in Commerical Banks Working in Jorden", Middle Eastern Finance and Economics, Issue 14, pp 60-74.

Navaratnaseelan, J.J. and Elangkumaran, P.(2014). "Impact of Service Quality on Customer Satisfaction: A Study on Customers of Commerical Bank of Ceylon PLC Trincomalee District", Faculty of Management and Finance, University of Ruhuna, pp 359-364.

Rahnama, Afshin; Alaei, Abbas; Shafaee, Javad; Ariana, Ali;(2012) "Evaluation of Relationship Marketing Dimension Effect on Degree of Customer's Loyalty of Insurance Industry in Iran" Journal of Basic and Applied Scientific Research, 2(2)1842-1848.

Rahnama, Afshin; Alaei, Abbas; Shafaee, Javad; Hamdam, Hadi;(2012) "Evaluating the Impact of Banking Services Quality on Customer Loyalty in Mellat Bank Ardebil Province" Journal of Basic and Applied Scientific Research, 2(3)2498-2506.

Rahnama, Afshin; Mousavian, Seyed Javad; Alaei, Abbas; Salimi Maghvan, Tavakkol;(2011) "The survey of relationship between creativity of staffs and organizational effectiveness" Australian Journal of Business and Management Research Vol.1 No.6 [97- 
104].

Ravichandran, K., Mani, B. T., Kumar, S. A., \& Prabhakaran, S., (2010), "Influence of service quality on customer satisfaction application of servqual model", International Journal of Business and Management, 5, 117-124.

Sahney, S., Banwet, D. K., \& Karunes, S., (2006), "An integrated framework for quality in education: A pplication of quality function deployment, interpretive structural modeling and path analysis", Total Quality Management, 17, 265-285.

SeyyedJavadin, Seyyed Reza, Khanlari, Amir and Steeri, Mehrdad (2010), "a model for evaluation of impact of service quality on sport services customers' loyalty", Olympic quarterly, number 4, pp: 41-54.

Shahin, Arash and Abolhasani, Zahra (2010), "evaluation of differences in service quality characteristics and service providing manner in insurance industry (case study: Iran Insurance Company in Isfahan Province)", journal of knowledge and development, number 31, pp: 75-96.

SobhaniFard, Yaser and AkhavanKharraziyan, Maryam (2011), "determination of strategic priority in order to improve servie quality of bank customers", strageic management studies, number 5, pp: 149-164.

Vazifehdoost, Hossein; Rahnama, Afshin; Mousavian, Seyed Javad; (2014), "Evaluation of the Impact of Brand Purchase Involvement, Satisfaction, Experience and Brand Trust on Loyalty to Brand" Mediterranean Journal of Social Sciences MCSER Publishing, Rome-Italy; Vol 5 № 20, pp: 3054-3063.

Zitamel, Valeri A and Parasuraman, A, (2008), "service quality", "translated by KambizHeidarzadeh and Ali Hajiha), Tehran: KasaKavosh publications, first printing. 